\title{
Processamento auditivo e consciência fonológica em crianças com aquisição de fala normal e desviante*****
}

\author{
Auditory processing and phonological awareness in children with \\ normal and deviant speech development
}

\author{
Victor Gandra Quintas* \\ Tiago Mendonça Attoni** \\ Márcia Keske-Soares*** \\ Carolina Lisbôa Mezzomo****
}

\begin{abstract}
*Fonoaudiólogo Clínico. Mestre em Distúrbios da Comunicação Humana pela Universidade Federal de Santa Maria - Rio Grande do Sul (UFSM/RS). Endereço para correspondência: Av. Dr. Guilhermino de Oliveira, $\mathrm{n}^{\circ} 466$ -

Contagem - MG - CEP: 32.341-290 (victorquintas@ymail.com).

**Fonoaudiólogo. Mestre em Distúrbios da Comunicação Humana pela UFSM/RS.

***Fonoaudióloga. Doutora em Linguística Aplicada pela Pontifícia Universidade Católica do Rio Grande do Sul (PUC/RS). Professora do Curso de Pós-Graduação em Distúrbios da Comunicação Humana da UFSM/RS.
\end{abstract}

****Fonoaudióloga. Doutora em Linguística Aplicada pela PUC/RS. Professora do Curso de Pós-Graduação em Distúrbios da Comunicação Humana da UFSM/RS.

*****Trabalho Realizado na UFSM/RS.

Artigo Original de Pesquisa

Artigo Submetido a Avaliação por Pares

Conflito de Interesse: não

\begin{abstract}
Background: auditory processing (AP) and phonological awareness (PA) in children with and without phonological disorders. Aim: to compare the performance of children with and without phonological disorders in a PA test; to verify the possible relationship between performances in distinct tasks of this test with the performance in the AP evaluation. Method: participants were 44 children with and without the diagnosis of phonological disorder, aged between 5:0 and 7:0 years, of both genders. After speech samples were gathered, subjects were divided into two groups: a study group (SG), composed by children with phonological disorders, and a control group (CG) with children without phonological disorders. PA was assessed through the Protocol Task Awareness Test (PTAT), and through the simplified AP evaluation (screening) - Disyllabic change - Staggered Spondaic Word (SSW), dichotic listening test and the binaural fusion test. Results: in both PA and AP assessments, children of the CG obtained better results. When correlating the results of AP and PA, a greater number of correlations were observed for the SG. Conclusion: a significant relationship between the performance in the AP evaluation and success in PA tasks exists for children with phonological disorders.
\end{abstract}

Key Words: Child; Speech; Hearing Tests.

\section{Resumo}

Tema: processamento auditivo (PA) e consciência fonológica (CF) em crianças com e sem desvio fonológico. Objetivo: comparar o desempenho de crianças com e sem desvio fonológico em teste de CF e verificar a possível relação entre os desempenhos nas distintas tarefas deste teste com o desempenho na avaliação do PA. Método: participaram da pesquisa 44 crianças com e sem diagnóstico de desvio fonológico, com idades entre 5:0 anos e 7:0 anos e de ambos os sexos. Após coleta da amostra de fala os sujeitos foram divididos em grupo estudo (GE), composto por crianças com desvio fonológico, e grupo controlo (GC) com crianças sem desvios fonológicos. Foi feita avaliação da CF por meio do uso do Protocolo de Tarefas de Consciência Fonológica (PTCF), e avaliação simplificada do PA (triagem), Teste de Dissílabos alterados - Staggered Spondaic Word (SSW), Teste Dicótico de Dígitos e o teste de Fusão binaural. Resultados: tanto na avaliação de CF quanto nas avaliações do PA, as crianças do GC obtiveram resultados superiores àqueles obtidos pelas crianças do GE. Ao correlacionar o PA com a CF, houve mais correlações no GE. Conclusão: há significativa relação entre o desempenho do PA e os êxitos obtidos nas tarefas de CF em crianças com desvios fonológicos.

Palavras-Chave: Criança; Fala; Testes Auditivos. 


\section{Introduction}

The process of acquisition and phonological development of the Brazilian Portuguese occurs gradually, until there is the establishment of the phonological system, according to the linguistic community where the child lives1. Some children do not have this profile of language acquisition, since they show deviations in the phonological process. These deviations are speech disorders without apparent organic etiology, with language disorders in the mental representation of speech sounds, which are called phonological deviation2. It is important to say that children with normal development begin to babble on around six to nine months old and the first words appear around ten to fifteen months old. The phonological system as a whole gets stable at around five years old3.

During the phonological acquisition, the child may reach a metacognitive level that helps him/her to understand the language, which shows us that, to read, it is needed to know to recode the language, i.e., to learn the correspondence between the phonemes of the language and the graphemes that represent them. To do so, it is necessary to manipulate the speech sounds, also called phonological awareness (PA) 4.

Therefore, it is believed that the difficulties in spoken language, including the phonological awareness deficit and phonological disorders, may be closely related to auditory processing disorders (APD), because the hearing is the main route for the language acquisition to become possible5-7.

Hearing is not only the act of hearing itself, it is made of mechanisms and processes of the system responsible for the behavioral phenomena, such as sound location, auditory discrimination, auditory recognition, resolution and temporal ordering, auditory performance with competitive beeps and auditory performance with degraded acoustic signals, which are called Auditory Processing (AP)6-8.

Despite the importance of the presented subject and its evident clinical implications, there are few studies in the current literature that relate the AP skills to the PA, as well as to the speech development. Thus, this research aims to investigate the relationship between the AP and the PA in groups of children with and without phonological disorders, drawing a comparison between the two profiles of language acquisition.

\section{Method}

This study is a prospective, transversal research, in which the phonological disorder is variabledependent and the test results of AP and PA constitute the independent variables. It was approved by the Ethics Committee in Research, from a Higher Education Institution, under number 0093.0.243.000-09. The data were collected in the second half of 2009, specifically from the month of August on.

The following inclusion criteria were considered for the children to be part of the study sample: The students' parents or guardians of the children, who accepted to take part in the study, should authorize them to participate in the research by signing the Consent Form; The right-handed students from both sexes but older than 5:0 years old should have a diagnosis of phonological disorder (PD) for the study group (SG) and normal phonological development for the control group (CG).

The following exclusion criteria were considered: Clear changes in the neurological, cognitive and / or psychological aspects of the child; . Evidence of hearing loss; Alteration of the stomatognathic system that could be related to changes in speech; Making use of musical instruments; Having had speech therapy before; Difficulty concentrating as checked during the speech sorting.

To select the sample of the study, the children, who were selected during the screening (sorting) at a public speech therapy service, were assessed. The number of children who took part in the research was based on the demand for speech care in the institution. All the children who met the described criteria were assessed individually in the institution and all of them went through a phonological screening test in which an informal assessment of receptive and expressive language was performed. There was also a complete phonological assessment for them with the AFC Avaliação Fonológica da Criança9, for children in which changes in the phonological inventory were observed. The AFC instrument consists of five pictures about specific themes in which the speech sample is collected by means of naming and spontaneous speech. In addition to this, whenever it was necessary, there were complementary neurological, otorrinolaringological and psychological assessments.

Thirty children went through the sorting. However, only 22 subjects, aged between 5:0 and $7: 0$ years old and average age of 6:3 years old, met 
the inclusion criteria to compose the sample for the SG. For the control group (CG), initially 25 children went through the screening, being 22 randomly selected with similar ages to the ones from the SG.

For the data collection, a Phonological Awareness Task protocol was applied (PATP)10: Segmentation of sentences into words (T1); Nominal Realism (T2); Rhymes Detection (T3), Syllabic Synthesis (T4); Syllable Segmentation (T5); Syllable Detection (T6); Syllable Reversal (T7); Phonemic Exclusion (T8); Phoneme Detection (T9), Phonemic Synthesis (T10); Phonemic Segmentation (S11); Phonemic Reversal (T12).

Besides the PATP, for the data collection, there was a simplified assessment of the auditory processing, the Dichotic Listening Tests (DL) - they consist of a word list (e.g. numbers) spoken simultaneously in a dichotic way; Binaural Fusion Test (BF) - a list of monosyllabic words acoustically distorted, and Alternate Dichotic Dissyllables (SSW) - a list of freely and competitively spoken words (free right to the competitive right to the competitive left to the free left, etc) - Processamento Auditivo Central:Manual de aplicação11. For the application of each test, it was taken into consideration the age pattern in which the listening skills were developed, as well as the literature references for the application of specific tests according to the age. All the tests were performed in acoustically treated booth without the interference of the environment, and they were applied by means of clinical audiometer of two channels, which belongs to Fonix FA - 12, and the use of a TDH 39 phone.
The assessments of the subjects, from the screening to the specific evaluations, were performed in two stages, on different days. Initially, the phonological sorting (screening), the hearing evaluation and the phonological assessment for the selection of the sample were performed. The children who have matched the inclusion criteria comprised the sample. At second, the assessments for data collection, including the performance on the PA and the AP evaluation, were performed. Statistical analysis was performed with SAS (Statistical Analysis System) software, version 8.02, with Pearson's Correlation Analysis Test, in which correlations above $50 \%$ and p $<0.05$ were considered.

\section{Results}

Table 1 shows the results of correct answers obtained in both the PA and the AP tasks in the SG and the $\mathrm{CG}$.

Table 2 shows the correlations between the correct answers in the tasks of the PA and the AP in the CG. The described correlations were the ones equal or above 0.50 and $\mathrm{p}<0.05$.

Table 3 shows the correlations between the correct answers in the tasks of the PA with the AP in the SG. The described correlations were the ones equal or above 0.50 and $\mathrm{p}<0.05$.

This table is also shows the correlation of PA with the degree of phonological disorder (DPD). No statistical analysis was performed between the two groups, comparing the performances in PA, since our goal is just to compare the performance of the PA in the group with phonological deviation and in the group with normal phonological acquisition. 
TABLE 1. Performance of correct answers in phonological awaren ess and aud itory processing tasks in the control and study groups.

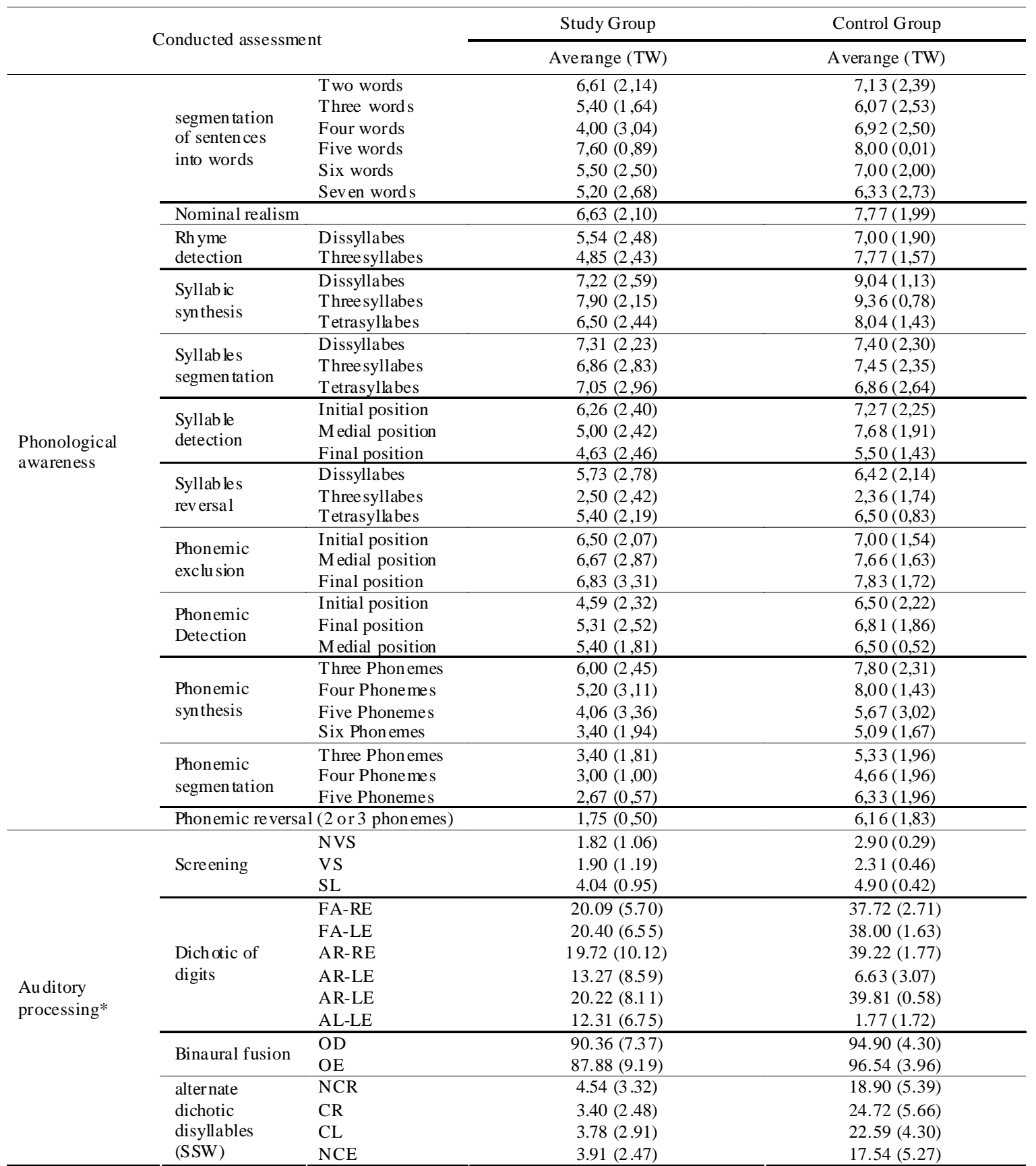

Legend: $\mathrm{NVS}=$ nonverbal sequence; $\mathrm{VS}$ = verbal sequence; $\mathrm{SL}=$ sound location; $\mathrm{FA}=$ free atten tion; $\mathrm{AR}=$ attention to the right; $\mathrm{AL}$ = attention to the left; $\mathrm{RE}=$ right ear; $\mathrm{LE}=$ left ear; $\mathrm{NCR}=$ non-competitive right; $\mathrm{CR}=$ competitive right; $\mathrm{CL}=$ competitive left; NCL = noncompetitive left. 
TABLE 2. Correlation between the auditory processing tests and the phonological awareness - control group.

\begin{tabular}{|c|c|c|c|c|c|c|c|c|c|c|c|}
\hline \multirow{2}{*}{\multicolumn{2}{|c|}{$\begin{array}{l}\text { Phonological Aw areness Tasks and Auditory } \\
\text { Processing Testing }\end{array}$}} & \multicolumn{3}{|c|}{ Screening } & \multicolumn{3}{|c|}{ Dichotic of digits } & \multicolumn{4}{|c|}{ SSW } \\
\hline & & NVS & VS & SL & $\mathrm{AR}$ & $\mathrm{RE}$ & $\mathrm{LE}$ & NCR & CR & $\mathrm{CL}$ & ENC \\
\hline \multirow{4}{*}{ Senten ces segmentation } & $2 \mathrm{P}$ & & - & - & - & - & - & - & - & - & - \\
\hline & $3 \mathrm{P}$ & - & 0,53 & - & - & - & - & - & - & - & - \\
\hline & $4 \mathrm{P}$ & - & - & 0,68 & - & - & - & - & - & - & - \\
\hline & $5 \mathrm{P}$ & - & - & - & - & - & - & 0,98 & - & - & - \\
\hline \multicolumn{2}{|l|}{ Nominal realism } & - & - & 0,58 & - & - & - & & - & - & - \\
\hline \multirow{3}{*}{ Syllabic synthesis } & Diss & - & - & - & - & - & - & - & - & - & - \\
\hline & Triss & - & - & - & - & - & - & - & - & - & - \\
\hline & Quadr & - & - & - & $\begin{array}{c}- \\
0,92\end{array}$ & - & - & 0,50 & - & - & $\begin{array}{c}- \\
0,55\end{array}$ \\
\hline \multirow[t]{2}{*}{ Segmentation syllab ic } & Triss & - & - & 0,52 & & - & - & - & - & - & - \\
\hline & Inicial & 0,54 & 0,71 & 0,52 & $\begin{array}{c}- \\
0,94\end{array}$ & - & - & - & - & - & - \\
\hline \multirow[t]{2}{*}{ Syllable detection } & Medial & - & - & - & - & - & 0,62 & - & - & - & - \\
\hline & Final & - & $\begin{array}{c}- \\
0,58 \\
\end{array}$ & - & - & - & - & - & - & - & - \\
\hline Syllable rev ersal & Quadr & - & $\begin{array}{c}- \\
0,79 \\
\end{array}$ & - & - & $\begin{array}{c}- \\
0,87 \\
\end{array}$ & & - & - & - & - \\
\hline \multirow{2}{*}{ Phonemes Detection } & Inicial & - & - & - & - & - & - & - & - & - & - \\
\hline & Final & - & - & - & - & - & - & - & - & - & - \\
\hline \multirow[t]{2}{*}{ Phonemic synthesis } & $6 \mathrm{~F}$ & - & - & - & - & - & - & - & - & $\begin{array}{c}- \\
0,96 \\
\end{array}$ & - \\
\hline & $5 F$ & - & - & - & - & - & - & - & $\begin{array}{c}- \\
0,95\end{array}$ & - & - \\
\hline \multicolumn{2}{|c|}{ Phonemic reversal with 2/3P } & - & - & - & - & - & - & 1,00 & - & - & - \\
\hline \multicolumn{12}{|c|}{$\begin{array}{l}\text { Legend: NVS = nonverbal sequence; VS = verbal response; } \mathrm{SL}=\text { sound location; } \mathrm{AR}=\text { attention to the right, } \mathrm{RE}=\mathrm{right} \text { ear, } \\
\text { listening to the right; } \mathrm{LE}=\text { left ear, listening to the left; } \mathrm{NCR}=\text { non competitive right; } \mathrm{CR}=\text { competitive right; } \mathrm{CL}=\mathrm{competitive} \mathrm{left;} \\
2 \mathrm{~W}=\text { two words: } 3 \mathrm{~W}=\text { three words; } 4 \mathrm{~W}=\text { four words; } 5 \mathrm{~W}=\text { five word s; Diss = two syllables; Triss = three syllables; tetra = } \\
\text { tetrasyllable; } 6 \mathrm{P}=\text { six phonemes; } 5 \mathrm{P}=\text { five phonemes; } 2 / 3 \mathrm{P}=\text { two or three phonemes. Only the correlation s above } 0.50 \text { with a } \\
\text { significance of p }<0.05 \text { were presented in the table. }\end{array}$} \\
\hline
\end{tabular}


TABLE 3. Correlation between the auditory processing tests and the phonological awareness - study group.

\begin{tabular}{|c|c|c|c|c|c|c|c|c|c|c|c|}
\hline \multirow{2}{*}{$\begin{array}{l}\text { Phonological Awarenes } \\
\text { and Auditory Processin }\end{array}$} & \multirow{2}{*}{$\begin{array}{l}\text { s Tasks } \\
\text { g Testing }\end{array}$} & \multirow{2}{*}{ DPG } & \multirow{2}{*}{$\begin{array}{c}\text { Triagem } \\
\text { NVS }\end{array}$} & \multicolumn{2}{|c|}{ Fusão Binaural } & \multicolumn{3}{|c|}{ Dicótico de Dígitos } & \multicolumn{3}{|c|}{ SSW } \\
\hline & & & & LD & $\mathrm{RE}$ & $\mathrm{AR}$ & ER & EL & NCR & CR & NCL \\
\hline \multirow{3}{*}{$\begin{array}{l}\text { Sentences } \\
\text { segmentation }\end{array}$} & $5 \mathrm{P}$ & - & - & - & - & - & -0.52 & - & - & - & - \\
\hline & $6 \mathrm{P}$ & - & - & - & - & - & -0.52 & -0.50 & - & - & - \\
\hline & $7 \mathrm{P}$ & - & - & - & - & - & -0.50 & - & - & 0,92 & - \\
\hline Rhyme detection & Triss & - & - & - & - & - & - & - & 0.59 & - & - \\
\hline \multirow{2}{*}{ Syllable detection } & Diss & - & -0.67 & - & - & - & - & - & 0.50 & - & - \\
\hline & Quadr & - & -0.62 & 0.50 & - & 0.50 & - & - & - & - & - \\
\hline \multirow{2}{*}{$\begin{array}{l}\text { Segmentation } \\
\text { syllabic }\end{array}$} & Diss & - & -0.61 & - & - & - & - & - & - & - & - \\
\hline & Quadr & 0.96 & - & - & - & - & - & - & 0,56 & 0,67 & - \\
\hline Syllable detection & Medial & - & - & - & -0.60 & -0.50 & - & - & - & - & - \\
\hline Syllable reversal & Tetra & - & - & - & - & - & -0.61 & -0.52 & - & - & - \\
\hline \multirow{2}{*}{ Phonemic exclusion } & Final & - & - & - & - & - & -0.56 & - & - & - & - \\
\hline & Medial & - & - & - & - & - & -0.52 & - & - & - & - \\
\hline \multirow{5}{*}{ Phonemic synthesis } & $1 \mathrm{~F}$ & - & - & - & - & - & -0.50 & - & - & - & - \\
\hline & $2 \mathrm{~F}$ & - & - & 0.50 & - & - & - & - & - & - & - \\
\hline & $3 \mathrm{~F}$ & - & - & - & - & - & -0.67 & -0.56 & - & - & - \\
\hline & $4 \mathrm{~F}$ & 0.95 & - & - & - & - & -0.71 & -0.50 & - & - & - \\
\hline & $6 \mathrm{~F}$ & - & - & - & - & - & - & - & - & - & 0,84 \\
\hline \multirow{2}{*}{$\begin{array}{l}\text { phonemic } \\
\text { segmentation }\end{array}$} & $4 \mathrm{~F}$ & - & - & - & - & - & -0.62 & - & - & - & 0,99 \\
\hline & $5 \mathrm{~F}$ & -1.0 & - & - & - & - & - & - & - & - & - \\
\hline
\end{tabular}

\section{Discussion}

The results of this research match the hypothesis that children with phonological disorders have problems in the AP and, hence, the PA skills may be affected as well12.

The PA, according to this research, and supported by the literature 4,13 , is not necessarily impaired in children with the acquisition of deviant speech, for the performances in the two populations surveyed was similar.

However, despite not having been performed a statistical analysis between the groups, it is possible to realize that children with normal phonological development have better performance in specific tasks than children with phonological disorders. This finding is similar to the ones from another study13.

Children from both groups, who took part in this study, had even lower scores in phonemic-level tasks as compared with the syllable-level ones, being the syllable reversion task the only one with similar values to those at the level of phonemes.
There is still a lack of studies regarding the association between the PA Deficit and the APD, although there seem to be a relationship between these variables, since the integrity of the physiological- auditory mechanisms has an important role in speech perception in learning and language comprehension. Thus, it is a basic principle in reading and writing acquisition14-17. This study, therefore, may show that there is a relationship between these two areas, as well as there are correlations between them.

In both groups, some negative correlations were found, which show that the results obtained in AP are inversely proportional to the PA, i.e. the more changes in Auditory Processing Tests, the lower the number of successes in the PA tasks will be.

For the degree of deviation, the results were not statistically significant for the AP, and they have not been tabulated, even though they were considered relevant for three PA tasks. These correlations were strong, being two of them positively and one negatively. 
The subtasks of syllable segmentation (tetrasyllable) and phonemic synthesis (four phonemes) showed the strongest, positive correlation. These findings suggest that the high degree of deviation may cause errors in these tasks. The subtask of phonemic segmentation (five phonemes) showed the strongest correlation in a negative way. This result suggests that the performance of this subtask may be better in children with higher degrees of disorders. Again, it must be emphasized that there are few studies that describe the relationship established by this

\section{References}

1. Vieira MG, Mota HB, Keske-Soares M. Relação entre idade, grau de severidade do desvio fonológico e consciência fonológica. Rev soc Bras Fonoaudiol. 2004;9(3):144-50.

2. Lewis BA, Freebairn LA, Hansen AJ, Stein CM, Shriberg LD, Iyengar SK, Taylor HG. Dimensions of early speech sound disorders: a factor analytic study. J comm disorders. 2006;39:139-57.

3. Wertzner HF, Amaro L, Galea DES. Phonological performance measured by speech severity indices compared with correlated factors. Sao paulo med j. 2007;125(6):30914

4. Rvachew S, Chiang P, Evans N. Characteristics of speech errors produced by children whit and without delayed phonological awareness skills. Language, Speech, and Hearing Services in Schools. 2007;38:60-71.

5. Chermak GD, Silva ME, Nye J, Hasbrouck J, Musiek FE. An update on professional education and clinical practices in central auditory. Journal of the american academy of audiology. 2007;18(5):428-52.

6. Psillas G, Psifidis A, Hitoglou-Antoniadou M, Kouloulas A. Hearing assessment in pre-school children with speech delay. Auris nasus larynx. 2006;33:259-63.

7. Bamiou DE, Musiek FE, Luxon LM. Aetiology and clinical presentations of auditory processing disorders- a review. Arch dis child. 2001;85:361-5.

8. American speech-language-hearing association. (2005). (central) auditory processing disorders [technical report].

9. Yavas MS, Hernandorena CLM, Lamprecht RR. Avaliação fonológica da criança: reeducação e terapia. Porto alegre: artes médicas; 1991.

10. Cielo CA . Habilidades em Consciência Fonológica em Crianças de 04 a 08 anos de idade. Pró-Fono. 2002; 14:287478. research, both in children with typical and with deviant acquisition. It is also true that studies on language acquisition sometimes just focus on the PA18-20.

\section{Conclusion}

Children with phonological disorders may show abnormalities in some AP tests, but PA tasks are not always changed. However, in comparison with children with normal phonological development, children with deviant phonological acquisition have lower performances either in AP tasks or in PA ones.
11. Pereira LD, Schochat E. Processamento auditivo central: manual de aplicação. São Paulo: lovise; 1997.

12. Stoel-Gammon C. Normal and disordered phonology in two-years-olds. Top lang disord. 1991;11(4):21-32.

13. Marchetti PT. Desempenho em consciência fonológica de crianças com desenvolvimento fonológico normal e desviante e a terapia fonológica. 2008. Dissertação (mestrado em disturbios da comunicação humana. Área de concentração - linguagem) - universidade federal de santa maria, santa Maria; 2008.

14. Bishop DV, Carlyon RP, Deeks JM, Bishop SJ. Auditory temporal processing impairment: neither necessary nor sufficient for causing language impairment in children. $\mathrm{J}$ speech lang hear res. 1999;42(6):1295-310

15. Watson BU, Miller T. Auditory perception, phonological processing and reading ability/disabilities. $\mathrm{J}$ speech hear res. 1993;36:850-63.

16. Boets $B$, Wouters $J$, van Wieringen $A$, Ghesquière $P$. Auditory processing, speech perception and phonological ability in pre-school children at high-risk for dyslexia: a longitudinal study of the auditory temporal processing theory. Neuropsychologia. 2007;45(8):1608-20.

17. Heath SM, Hogben JH, Clark CD. Auditory temporal processing in disabled readers with and without oral language delay. J child psychol psychiatry. 1999;40(4):637-47.

18. Tallal P. Auditory temporal perception, phonics and reading disabilities in children. Brain lang. 1980;9:182-98.

19. Murphy CFB e Schochat E. How auditory temporal processing deficits relate to dyslexia. Brazilian journal of medical and biological research. 2009;42:647-54.

20. Engelmann L, ferreira MIDC. Avaliação do processamento auditivo em crianças com dificuldades de aprendizagem. Rev soc. Brás. fonoaudiol. 2009;14(1):6974. 